\title{
TIMING OF LATE PALAEOPROTEROZOIC METAMORPHISM IN THE NORTHERN BELOMORIAN BELT, WHITE SEA REGION: CONCLUSIONS FROM U-Pb ISOTOPIC DATA AND P-T EVIDENCE
}

\author{
TORBJÖRN SKIÖLD, SVETLANA BOGDANOVA, \\ ROLAND GORBATSCHEV and ELENA BIBIKOVA
}

SKIÖLD, TORBJÖRN, BOGDANOVA, SVETLANA, GORBATSCHEV, ROLAND and BIBIKOVA, ELENA 2001. Timing of late Palaeoproterozoic metamorphism in the northern Belomorian Belt, White Sea region: conclusions from $\mathrm{U}-\mathrm{Pb}$ isotopic data and P-T evidence. Bulletin of the Geological Society of Finland 73, Parts 1-2, 59-73.

Brilliant-looking zircon crystals from a garnet-amphibolitic, metamorphosed mafic dyke at Lyagkomina in the Lake Kovdozero area, northern Belomorian Belt, most probably mark the $1875 \pm 4$ Ma age of peak late Palaeoproterozoic regional metamorphism which followed upon dyke intrusion associated with deformation of the Lapland-Kola orogenic tectonic collage. U-Pb ages of titanites (ca. $1860 \mathrm{Ma}$ ) and rutiles (ca. $1750 \mathrm{Ma}$ ) help reconstruct the retrograde path and the cooling rates which decreased with time. The new titanite and rutile ages agree well with similar age data previously obtained on a regional scale from the central part of the belt and suggest absence of variation in mineral ages as a function of lithological differences. P-T analysis of the metamorphic parageneses indicates initial sharp decompression after peak metamorphism and jump uplift with unroofing of ca. 9-10 km of the crust in the Belomorian Belt previously thickened by late Palaeoproterozoic orogenic thrusting and stacking.

Key words: metamorphism, $\mathrm{P}-\mathrm{T}$ conditions, absolute age, $\mathrm{U} / \mathrm{Pb}$, zircon, titanite, rutile, Paleoproterozoic, Lyagkomina, Russian Federation

Torbjörn Skiöld: Swedish Museum of Natural History, P.O. Box 50007, S-104 05 Stockholm, Sweden

Svetlana Bogdanova and Roland Gorbatschev: Department of Geology, Lund University, Sölvegatan 13, S-223 62 Lund, Sweden

Elena Bibikova: Vernadsky Institute of Geochemistry and Analytical Chemistry, Russian Academy of Sciences, Kosygin Street 19, RU-117975 Moscow, Russia 


\section{INTRODUCTION}

The Belomorian Belt along the south-western shore of the White Sea (Fig. 1) is one of the principal crustal units in the Archaean, eastern part of the Baltic (Fennoscandian) Shield. It is structurally complex and has undergone repeated metamorphism, the different mineral associations overprinting each other. Largely because of this complexity, the Belomorian Belt has long been regarded as the ancient core of the Archaean domain.

A completely different interpretation, however, was proposed by Gaál and Gorbatschev in 1987. These authors see the Belomorian as a mobile belt which in the Neoarchaean had collided with the Karelian protocraton and in late Palaeoproterozoic times had been compressed between that protocraton and the Archaean terranes of the Kola Peninsula. Subsequent work confirmed the validity of this reinterpretation.
The present study focuses on the late Palaeoproterozoic development of the Belomorian Belt. The U-Pb age of brilliant-looking zircons in a deformed and metamorphosed mafic dyke is assumed to date approximately the peak of late $\mathrm{Pa}$ laeoproterozoic metamorphism, and provide a reference point which cannot be obtained from the surrounding high-grade Archaean country rocks where zircons are complex and separate grains of relevant age could not be detected. The dated dyke also makes it possible to distinguish between early and late stages of deformation and metamorphism.

In addition, $\mathrm{U}-\mathrm{Pb}$ dating of titanite and rutile opens a way to assess the final stages of the late Palaeoproterozoic metamorphic evolution. In that regard there is a close relationship between the present paper and the titanite - rutile datings recently published by Bibikova et al. (2001). However, while the latter study aimed at regional, large-scale investigation of the Belomorian Belt

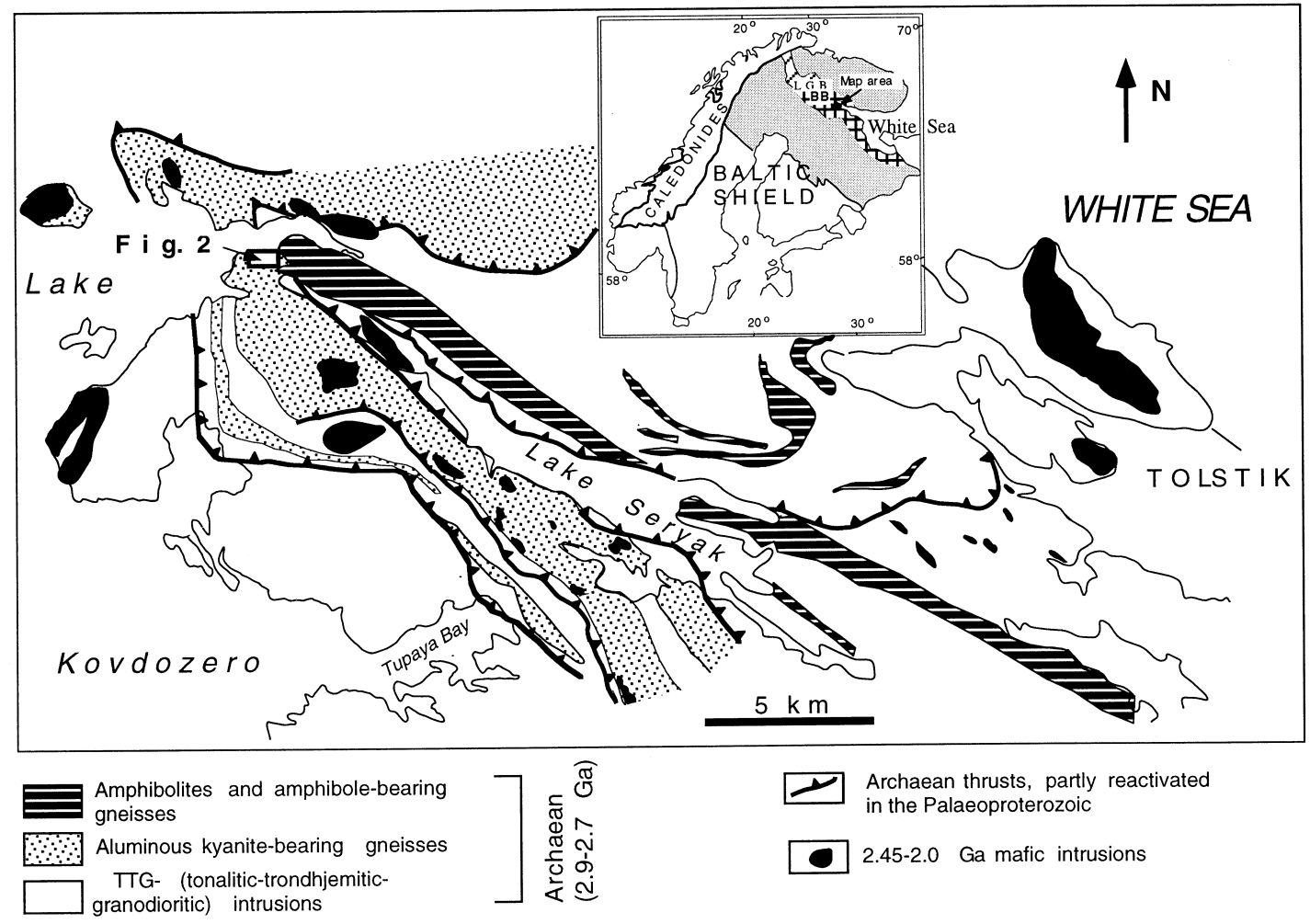

Fig. 1. Sketch map of the Kovdozero-Tolstik area in the northern part of the Belomorian Belt (modified after Balagansky et al. 1986, Stepanov \& Slabunov 1989, Miller \& Milkevich 1995). The Lyagkomina Dam area (Fig 2) is shown as a rectangle. 
and its south-western, Karelian foreland, the present project concentrates on an area of limited size (Fig. 1), where a range of lithologies can be compared.

\section{REGIONAL SETTING: EVOLUTION OF THE BELOMORIAN BELT}

The Belomorian Belt was formed in the Neoarchaean after ca. $2.9 \mathrm{Ga}$, apparently outboard the Karelian protocraton to which it was accreted ca. $2.7 \mathrm{Ga}$ ago (Bibikova et al. 1993 and 1996, Bogdanova \& Bibikova 1993, Miller \& Mil'kevich 1995). The accretion is considered to have involved subduction beneath the protocraton as well as thrusting of the Belomorian rocks to the west. The one-time thrust planes, like the one along Lake Seryak (Fig. 1), are still among the most conspicuous mega-features of the Belomorian Belt.

The lithologies formed during the early development stages of the belt comprise the Chupa and Khetolambina rocks, terms which originally were used in a stratigraphic sense. The Chupa rocks are aluminous gneisses with greywacke and pelite protoliths. The Khetolambina rocks, in contrast, are principally basaltic to andesitic amphibolites. Both these supracrustal lithologies have been intruded by plutonic rocks of the TTG (tonalite-trondhjemite-granodiorite) association. Neoarchaean metamorphism featured a complicated sequence of events but, in brief, it involved a granulitic phase at moderately high pressures, succeeded by retrogression until ca. $2.6 \mathrm{Ga}$.

In the late Palaeoproterozoic, the Belomorian Belt was once more involved in orogenic processes, now during the Lapland-Kola orogeny at ca. 1.9$1.8 \mathrm{Ga}$ (e.g. Bridgwater et al. 1992). That orogeny included continent collision between the Archaean terranes of the Kola Peninsula and the combined Karelian-Belomorian protocraton which had been developed in the Neoarchaean. The Belomorian Belt became involved in thrusting, was thickened, and finally subjected to folding and regional metamorphism. Its Neoarchaean suture boundary towards the Karelian crustal domain continued to act as a discontinuity and therefore became the site of particularly intense and long-lived hydrothermal and pegmatite-generating igneous activity with the youngest $\mathrm{U}-\mathrm{Pb}$ titanite ages in the whole Belomorian region (Bibikova et al. 2001).

In the present context, it is of interest to note that during the late Palaeoproterozoic the titanite ages were completely reset and new rutile crystallized in the Belomorian Belt but not in the former cratonic nucleus in Karelia (Bibikova et al. 2001). In our recent U-Pb zircon studies of the Belomorian gneisses we have found a number of cases where discordant $\mathrm{U}-\mathrm{Pb}$ zircon data point at lower concordia-discordia intercepts of roughly 1.9-1.8 Ga (Bibikova et al. 1996). On the other hand, zircon newly formed during that time span appears to be rare, and independent new crystals are few if present at all.

The time between the two orogenies comprised an early stage of rifting. Then followed bimodal plutonic igneous activity with a dominant mafic mode and associated $2.45-2.35$ Ga high- to medium-grade metamorphism together with shearing and folding in the lower crust (Bogdanova \& Bibikova 1993; Bridgwater et al. 1994, Bogdanova 1996, and references in these articles).

\section{GEOLOGY OF THE LYAGKOMINA AND TUPAYA BAY LOCALITIES}

All the three principal Neoarchaean lithologies of the Belomorian Belt are exposed in the Lyagkomina Dam area by Lake Kovdozero (Fig. 2). In the north-west, almost monomineralic amphibolites associate with diopside-clinozoisite- and garnetdominated gneisses which belong to the Khetolambina complex of ultramafic and mafic metamorphosed volcanics and intrusions. In the southeast, garnet-biotite-kyanite-muscovite-bearing Chupa gneisses border on foliated TTG-type plutonic rocks.

Three main stages of deformation can be distinguished in the area (Fig. 2). In the Neoarchaean, ductile overthrusting of Khetolambina amphibolites and mafic gneisses over the Chupa-type aluminous gneisses and some small-scale recumbent folding occurred. Thereafter followed an as- 


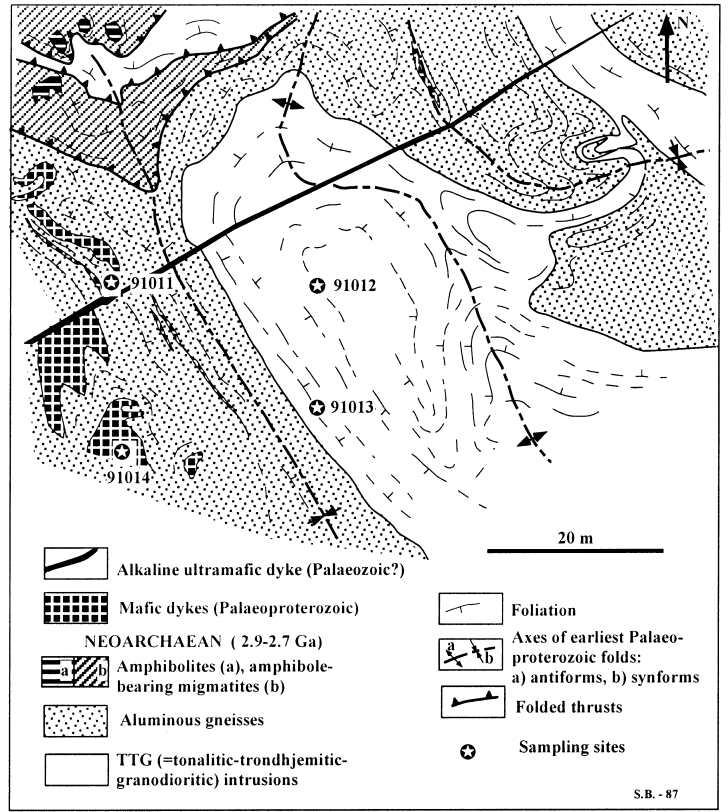

Fig. 2. Geological map of the Lyagkomina Dam locality, based on mapping by S.B. in 1987. Points 9101191014 indicate localities sampled for isotope analysis.

sumedly early Palaeoproterozoic stage when the Neoarchaean supracrustal rocks together with the TTG-type intrusions were deformed into major, moderately inclined, close folds with NW-trending axes. We associate this stage of folding with the one that appears to be related to shearing, highgrade metamorphism and bimodal gabbroic-granitic igneous activity at 2.5-2.4 Ga in the Tolstik area by the White Sea (Fig. 1, cf. Bogdanova \& Bibikova 1993, Bridgwater et al. 1994, Bogdanova 1996, Lobach-Zhuchenko et al. 1998, Claesson et al. in preparation).

The metamorphosed dykes, one of which has been investigated and dated in the present study (locality 91014 in Fig. 2), appear to separate that stage of deformation from a late Palaeoproterozoic one at a time when preexisting folds were flattened and folding of the dyke into small recumbent folds occurred. Subsequently followed boudinaging as well as migmatitic and pegmatitic veining in the enclosing aluminous gneisses. The dyke itself, however, is only weakly affected along its contacts with the host rocks.

Because of suspected disequilibrium among the minerals of the metamorphic assemblages, it has been diffucult to assign specific P-T values to the late Neoarchaean evolution. We estimate, however, that the garnet \pm kyanite \pm biotite + plagioclase + quartz assemblage in the Chupa gneisses (Bibikova et al. 1993) had reached temperatures of $750-800^{\circ} \mathrm{C}$ at pressures of $10-12$ kbar during the peak phase. A plausible hypothesis is that this occurred in association with the intrusion of ca. 2.73-Ga diorites along thrusts. Later, a retrograde amphibolitic stage was completed presumably by ca. 2.6 Ga. However, similar metamorphism has also been encountered among 2.45-2.40 Ga mafic intrusions in the Tolstik Peninsula (Fig. 1, cf. Bogdanova 1996 and references therein). A final phase of low-grade retrogression took place during uplift (cf. Miller et al. 1995, Skiöld et al. 1997) from about $1.9 \mathrm{Ga}$ ago.

The Tupaya Bay locality (SE of Lyagkomina in Fig. 1) allows a relatively better documentation of several stages of Neoarchaean metamorphism which here reached conditions of $800^{\circ} \mathrm{C}$ at $10 \mathrm{kbar}$ (cf. Balagansky et al. 1986, Bogdanova \& Bibikova 1993, Lobach-Zhuchenko et al. 1993). The 2.45-Ga granitic intrusions of this locality were also deformed, and this late development of amphibolite-facies mineral assemblages tentatively corresponds to the stage of dyke intrusions and subsequent metamorphism at Lyagkomina.

\section{ISOTOPIC WORK}

\section{The investigated rocks}

Titanites and rutiles from the Neoarchaean rocks of the Lyagkomina Dam locality (91011 to 13 in Fig. 2) and from Tupaya Bay were separated to be investigated isotopically. Previously, zircons from the same rocks had yielded $\mathrm{U}-\mathrm{Pb}$ ages in excess of $2.72 \mathrm{Ga}$ (Bibikova et al. 1996).

Lyagkomina sample 91011 is a heterogeneous migmatite that has been formed from Chupa-type aluminous gneisses. It contains coarse-grained, white or slightly yellowish pegmatitoid veins and quartz-feldspar segregations. The migmatitic matrix contains small lenticular slivers of metasedimentary protolith separated by zones of quartz- and 
muscovite-bearing foliated rock. These zones trend parallel to the migmatitic banding and were presumably formed more or less simultaneously with the pegmatitic veins. The gneiss contains kyanite, garnet, andesine, K-feldspar, biotite and quartz with accessory zircon, apatite, titanite and rutile.

Samples 91012 and 91013 are from the central and marginal parts, respectively, of a TTG-type rock body at Lyagkomina. Sample 91012 represents a nebulitic migmatite with lenticular quartz segregations, while light-reddish feldspar bands occur in a darker bluish-grey plagioclase-rich palaeosome in sample 91013. Micas accentuate the foliation and there are also rare grains of red garnet. The rocks are migmatised tonalites to granodiorites, sometimes with preserved relics of relatively coarse-grained subhedral andesine containing fine-grained inclusions of likewise subhedral amphibole, biotite and quartz. The plagioclase is deformed and partly recrystallized. Accessory apatite and zircon \pm magnetite appear to belong to the igneous association and are often enclosed within coarser-grained andesine. Rutile mostly occurs as inclusions in the quartz crystals. Titanite, biotite intergrown with muscovite, albite, and fine-grained muscovite convey a banded character to these rocks.

Apart from Neoarchaean supracrustal and plutonic lithologies, the Lyagkomina locality also features later mafic dyke intrusions. Sample 91014 is from such a dyke of approximately dioritic chemical composition that has been intruded into the local Chupa-type aluminous gneisses. In spite of remains of igneous plagioclase, the present mineral set-up is wholly metamorphic, garnet and hornblende being the most prominent dark phases, with some clinopyroxene similarly present. The metamorphic mineral association also includes most of the zircons. While there is age evidence that some zircon grains have been captured from older rocks (cf. below), virtually none of those analysed appear to have formed during the igneous crystallization of the dyke. Additional particulars of chemistry and mineral composition are given in the following sections on P-T work and $\mathrm{U}-\mathrm{Pb}$ data (see also Table 1).

Compared with the strong Palaeoproterozoic re- working at Lyagkomina, the one at Tupaya Bay has been relatively weak. In a previous study of the latter region, Bibikova et al. (1996) could date several Archaean igneous and metamorphic events using zircon U-Pb chronology. That paper and several others (e.g. Bibikova et al. 1993, Bogdanova \& Bibikova 1993, Lobach-Zhuchenko et al. 1993) in addition provide accounts of the Neoarchaean and later lithologies now sampled from the Tupaya Bay area. In the present study, titanites were dated also from the ca. $2.45 \mathrm{Ga}$ old potassic granites (cf. Bibikova et al. 1993) close to Tupaya Bay (Fig. 1).

\section{Methods}

The chemical preparation of the mineral samples selected for radiometric age determination followed conventional isotope dilution methods originally described by Krogh (1973 and 1982). The total Pb blank for our small-scale zircon procedure was 7 to 15 picogram during the course of this project. Additional steps involving treatment with bromic acid increased the blank level of the titanites and rutiles to $10-20$ picogram. Isotopic data were obtained in static mode on samples mixed with 205233-235 tracer using a Finnigan 261 spectrometer. Data processing was carried out according to Ludwig (1991a and b), using the decay constants recommended by Steiger and Jäger (1977).

\section{P-T WORK ON METAMORPHIC MINERALS}

The P-T conditions of the investigated mineral associations in the metamorphosed Lyagkomina amphibolitic dykes were assessed by employing the Perchuk et al. (1985) garnet-amphibole thermometer, the Kohn \& Spear (1990) garnet-plagioclase-amphibole barometers, and the Plusnina (1982) amphibole-plagioclase thermobarometer. The computer program "Geothermobarometry", coded by M. Kohn (Spear et al. 1991), was also employed. Estimates of the P-T conditions for the peak and retrograde stages of metamorphism were obtained from core-core and rim-rim mineral relationships, respectively. 
In contrast to the Neoarchaean, often nearly ultramafic amphibolites in the region (cf. Stepanov \& Slabunov 1989), the Lyagkomina dykes are more silicic, with $\mathrm{SiO}_{2}$-contents between 54.0 and $55.6 \%$ and $\mathrm{Na}_{2} \mathrm{O}+\mathrm{K}_{2} \mathrm{O}$ contents between 1.84 and $3.18 \%$. The mineral assemblages evidence a less complex metamorphic history than that of the Archaean amphibolites. The igneous assemblage is represented by relic subhedral plagioclase. Otherwise, the rocks mainly compose garnet, hornblende, rare clinopyroxene, labradorite, biotite and quartz. Zircon, allanite, apatite, opaques and rutile are accessories. Small amounts of titanite are also present. Scapolite, calcite, leucoxene and chlorites are partly replacing plagioclase, hornblende and biotite.

\section{RESULTS}

\section{Stages and P-T conditions of metamorphism}

Microprobe analyses of minerals from the garnetamphibolitic mafic dyke at Lyagkomina (sample 91014) are reported in Table 1.

Two metamorphic mineral assemblages, which were formed at somewhat different times, can be distinguished. The early one is represented by relatively coarser-grained subhedral garnet (Pyp1719Gros32-33Alm44-46Spes3-4), pargasitic hornblende $\left(\mathrm{Al}_{\mathrm{tot}} 2.5-2.7\right)$, biotite, plagioclase (An4954) and quartz (see Table 1). These minerals form coarse intergrowths and define the nematoblastic texture of the rock. This earlier assemblage yield-

Table 1. Representative microprobe analyses of metamorphic minerals from the Lyagkomina dyke.

\begin{tabular}{|c|c|c|c|c|c|c|c|c|c|c|c|c|c|}
\hline \multirow[b]{2}{*}{ Mineral* } & \multirow[b]{2}{*}{ grt 7} & \multicolumn{9}{|c|}{ Peak assemblages } & \multirow[b]{2}{*}{ pl31 } & \multirow[b]{2}{*}{ pl32 } & \multirow[b]{2}{*}{ pl53 } \\
\hline & & grt 11 & grt 12 & $\operatorname{grt39}$ & $\operatorname{grt} 40$ & $\operatorname{grt} 41$ & amph 22 & amph23 & $\operatorname{amph} 25$ & amph63 & & & \\
\hline $\mathrm{SiO} 2$ & 37.66 & 38.5 & 37.9 & 38.11 & 38.02 & 38.15 & 43.66 & 43.1 & 43.41 & 43.16 & 55.09 & 55.17 & 53.19 \\
\hline $\mathrm{A} 12 \mathrm{O} 3$ & 21.73 & 21.86 & 21.75 & 21.69 & 21.7 & 22.21 & 14.53 & 15.23 & 15.2 & 15.13 & 28.73 & 28.43 & 28.8 \\
\hline $\mathrm{FeO}$ & 21.23 & 21.43 & 21.85 & 21.91 & 21.94 & 22.38 & 13.49 & 13.64 & 14.03 & 13.53 & 0.17 & 0.15 & 0.08 \\
\hline $\mathrm{MgO}$ & 4.81 & 5.06 & 4.66 & 4.66 & 4.72 & 4.82 & 11.26 & 11.04 & 10.91 & 10.94 & 0.03 & 0.01 & 0.07 \\
\hline $\mathrm{CaO}$ & 11.72 & 11.57 & 11.51 & 11.62 & 11.71 & 11.35 & 11.91 & 12.11 & 12.14 & 12.18 & 10.56 & 10.17 & 11.11 \\
\hline $\mathrm{Na} 2 \mathrm{O}$ & 0 & 0.07 & 0.05 & 0 & 0.08 & 0.04 & 0.99 & 1.09 & 1.12 & 1.07 & 5.55 & 7.72 & 4.92 \\
\hline $\mathrm{K} 2 \mathrm{O}$ & 0.02 & 0.01 & 0.03 & 0.01 & 0 & 0.03 & 0.64 & 1.05 & 0.84 & 1.42 & 0.09 & 0.08 & 0.04 \\
\hline $\mathrm{TiO} 2$ & 0.7 & 0.05 & 0.02 & 0.04 & 0.05 & 0.02 & 0.93 & 0.93 & 0.94 & 1.14 & 0.03 & 0.02 & 0.03 \\
\hline $\mathrm{MnO}$ & 1.32 & 1.2 & 1.53 & 1.53 & 1.42 & 1.46 & 0.25 & 0.24 & 0.22 & 0.14 & 0.01 & 0.03 & 0.01 \\
\hline $\mathrm{Cr} 2 \mathrm{O} 3$ & 0.02 & 0.01 & 0.02 & 0.16 & 0.06 & 0.05 & 0.08 & 0.15 & 0.15 & 0.11 & 0.01 & 0.01 & 0.01 \\
\hline $\mathrm{Si}$ & 2.941 & 2.981 & 2.957 & 2.964 & 2.954 & 2.941 & 6.4 & 6.295 & 6.316 & 6.298 & 2.476 & 2.462 & 2.442 \\
\hline $\mathrm{Al}$ & 2 & 1.994 & 2 & 1.988 & 1.987 & 2.018 & 2.51 & 2.622 & 2.606 & 2.601 & 1.522 & 1.495 & 1.558 \\
\hline $\mathrm{Fe} 3$ & 0.036 & 0.049 & 0.092 & 0.071 & 0.108 & 0.104 & 0 & 0 & 0 & 0 & 0 & 0 & 0 \\
\hline $\mathrm{Fe} 2$ & 1.351 & 1.339 & 1.334 & 1.355 & 1.317 & 1.339 & 1.654 & 1.666 & 1.707 & 1.651 & 0.006 & 0.006 & 0.003 \\
\hline $\mathrm{Mg}$ & 0.56 & 0.584 & 0.541 & 0.54 & 0.546 & 0.553 & 2.461 & 2.404 & 2.367 & 2.379 & 0.002 & 0.001 & 0.005 \\
\hline $\mathrm{Ca}$ & 0.981 & 0.96 & 0.962 & 0.968 & 0.975 & 0.937 & 1.87 & 1.895 & 1.892 & 1.903 & 0.509 & 0.486 & 0.547 \\
\hline $\mathrm{Na}$ & 0 & 0.01 & 0.007 & 0.001 & 0.012 & 0.006 & 0.281 & 0.309 & 0.315 & 0.304 & 0.484 & 0.668 & 0.438 \\
\hline $\mathrm{K}$ & 0.002 & 0.001 & 0.003 & 0.001 & 0 & 0.003 & 0.12 & 0.196 & 0.156 & 0.264 & 0.005 & 0.004 & 0.002 \\
\hline $\mathrm{Ti}$ & 0.041 & 0.003 & 0.001 & 0.002 & 0.003 & 0.001 & 0.102 & 0.102 & 0.103 & 0.125 & 0.001 & 0.001 & 0.001 \\
\hline $\mathrm{Mn}$ & 0.087 & 0.078 & 0.101 & 0.101 & 0.094 & 0.095 & 0.032 & 0.03 & 0.027 & 0.017 & 0 & 0.001 & 0.001 \\
\hline $\mathrm{Cr}$ & 0.001 & 0.001 & 0.001 & 0.01 & 0.004 & 0.003 & 0.01 & 0.017 & 0.017 & 0.012 & 0 & 0 & 0 \\
\hline $\mathrm{mg}$ & 29 & 30 & 29 & 29 & 29 & 29 & 60 & 59 & 58 & 59 & 25 & 15 & 61 \\
\hline Albite & $\bullet$ & • & $\bullet$ & $\bullet$ & • & • & $\bullet$ & • & • & • & 48.5 & 57.7 & 44.4 \\
\hline Anorthite & $\bullet$ & - & - & $\bullet$ & $\bullet$ & - & - & - & $\bullet$ & - & 51.0 & 42.0 & 55.4 \\
\hline Orthoclase & $\bullet$ & $\bullet$ & $\bullet$ & - & $\bullet$ & $\bullet$ & $\bullet$ & $\bullet$ & $\bullet$ & $\bullet$ & 0.5 & 0.4 & 0.2 \\
\hline
\end{tabular}


ed a P-T estimate of $650 \pm 30^{\circ} \mathrm{C}$ at $8.5-9.5 \mathrm{kbar}$.

The apparently later metamorphic assemblage is made up of light-coloured hornblende, which is more edenitic and contains less Ti than the early one, garnet (Pyp16-18Gros27-30Alm48-49Spes46), labradorite (An60-66) and quartz. These minerals form intergrowths that surround and separate early garnet from hornblende and biotite, a situation we believe to be related to a decompressional trend in the metamorphic evolution. This particular stage is estimated to have occurred at $630 \pm 20^{\circ} \mathrm{C}$ and $7-8 \mathrm{kbar}$.

The obtained difference between the two metamorphic stages, which represent roughly similar temperatures at falling pressures, indicates nearisothermal decompression and rapid uplift in a collisional-type environment. The presently recorded metamorphic conditions in the dyke are

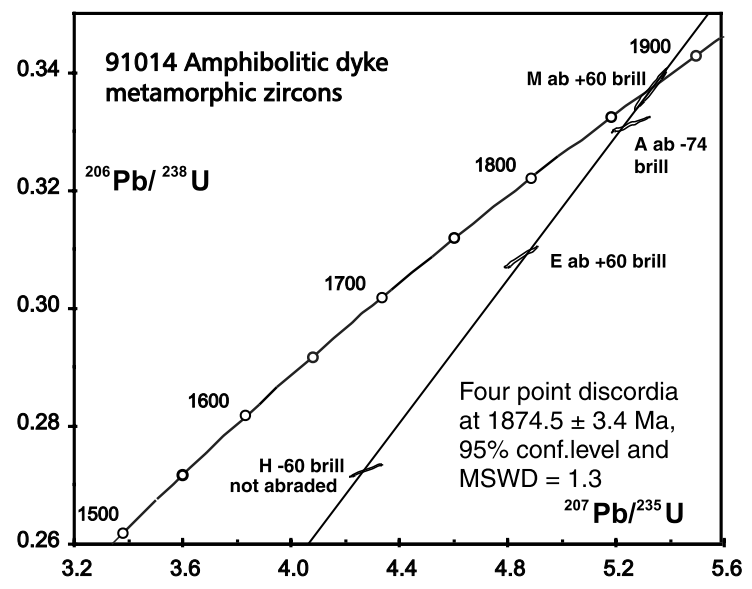

Fig. 3. Concordia diagram for zircons of sample 91014 from the Lyagkomina area. The discordia is based on the four brilliant-type zircon analyses reported in Table 2.

* grt - garnet, amph - amphibole, pl-plagioclase. All mineral calculations are made by MINTAB software. The minerals were analysed with GEOL-JSM-6400 (Lund University) using natural standards and ZAF correction program.

\begin{tabular}{|c|c|c|c|c|c|c|c|c|c|c|}
\hline \multicolumn{11}{|c|}{ Retrograde assemblages } \\
\hline grt13 & grt14 & $\operatorname{grt} 43$ & grt61 & grt70 & amph47 & amph 48 & amph68 & pl15 & pl17 & pl52 \\
\hline 37.9 & 37.82 & 38.48 & 38.26 & 38.36 & 41.73 & 42.23 & 42.45 & 52.19 & 51.8 & 50.78 \\
\hline 21.69 & 21.57 & 22.08 & 21.92 & 22.12 & 15.45 & 15.13 & 15.27 & 31.34 & 31.08 & 31.02 \\
\hline 21.69 & 22.37 & 21.75 & 22.39 & 21.79 & 14.31 & 13.84 & 13.77 & 0.24 & 0.17 & 0.09 \\
\hline 4.58 & 4.58 & 4.99 & 4.17 & 4.73 & 10.41 & 10.48 & 10.83 & 0.01 & 0.17 & 0.01 \\
\hline 12.02 & 10.89 & 12.13 & 11.82 & 12.1 & 11.76 & 11.91 & 12.13 & 12.39 & 13.09 & 13.3 \\
\hline 0.49 & 0.08 & 0.06 & 0.02 & 0.05 & 1.22 & 1.17 & 1.15 & 4.04 & 4.03 & 3.79 \\
\hline 0.01 & 0.01 & 0.04 & 0.01 & 0 & 1.09 & 0.88 & 1.39 & 0.53 & 0.04 & 0.03 \\
\hline 0.07 & 0.1 & 0.02 & 0.04 & 0.02 & 0.94 & 0.9 & 1.07 & 0.56 & 0.01 & 0.01 \\
\hline 1.48 & 1.87 & 1.26 & 2.01 & 1.41 & 0.26 & 0.25 & 0.2 & 0.02 & 0.03 & 0.07 \\
\hline 0.13 & 0.2 & 0.08 & 0.2 & 0.05 & 0.17 & 0.18 & 0.15 & 0.02 & 0.02 & 0.03 \\
\hline 2.925 & 2.954 & 2.948 & 2.964 & 2.95 & 6.209 & 6.281 & 6.238 & 2.34 & 2.342 & 2.327 \\
\hline 1.973 & 1.986 & 1.993 & 2.002 & 2.005 & 2.71 & 2.652 & 2.645 & 1.656 & 1.656 & 1.676 \\
\hline 0.236 & 0.094 & 0.116 & 0.098 & 0.098 & 0 & 0 & 0 & 0 & 0 & 0 \\
\hline 1.164 & 1.367 & 1.278 & 1.451 & 1.304 & 1.781 & 1.722 & 1.693 & 0.009 & 0.006 & 0.003 \\
\hline 0.527 & 0.533 & 0.569 & 0.481 & 0.543 & 2.309 & 2.323 & 2.372 & 0.001 & 0.012 & 0.001 \\
\hline 0.993 & 0.912 & 0.995 & 0.981 & 0.997 & 1.875 & 1.898 & 1.909 & 0.595 & 0.634 & 0.653 \\
\hline 0.073 & 0.012 & 0.009 & 0.003 & 0.008 & 0.352 & 0.338 & 0.329 & 0.351 & 0.353 & 0.337 \\
\hline 0.001 & 0.001 & 0.004 & 0.002 & 0 & 0.207 & 0.167 & 0.261 & 0.03 & 0.002 & 0.002 \\
\hline 0.004 & 0.006 & 0.001 & 0.002 & 0.001 & 0.106 & 0.1 & 0.118 & 0.019 & 0 & 0 \\
\hline 0.096 & 0.124 & 0.082 & 0.132 & 0.092 & 0.033 & 0.032 & 0.025 & 0.001 & 0.001 & 0.003 \\
\hline 0.008 & 0.012 & 0.005 & 0.010 & 0.003 & 0.02 & 0.021 & 0.017 & 0.001 & 0.001 & 0.001 \\
\hline 31 & 28 & 31 & 25 & 29 & 56 & 57 & 58 & 10 & 65 & 19 \\
\hline • & • & • & • & • & • & • & • & 36.0 & 35.7 & 34.0 \\
\hline • & • & • & • & • & • & • & $\bullet$ & 60.9 & 64.0 & 65.8 \\
\hline • & • & - & • & • & • & $\bullet$ & $\bullet$ & 3.1 & 0.2 & 0.2 \\
\hline
\end{tabular}




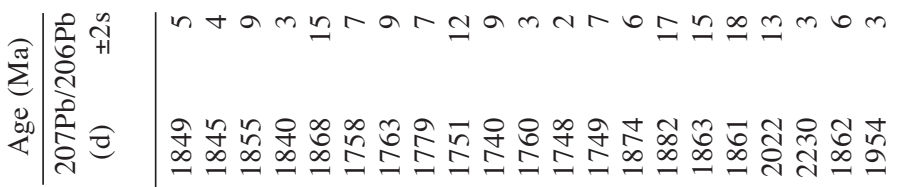

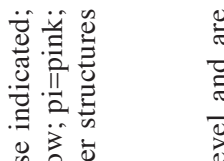

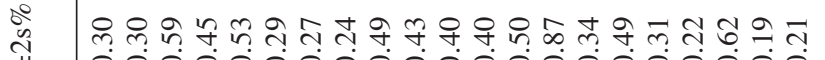
$\infty$

$\widehat{\Xi}$

造

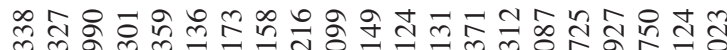

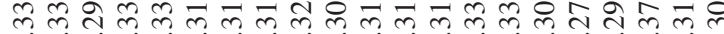

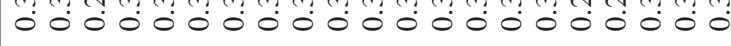

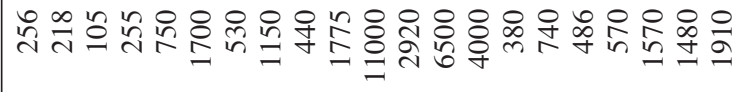
党

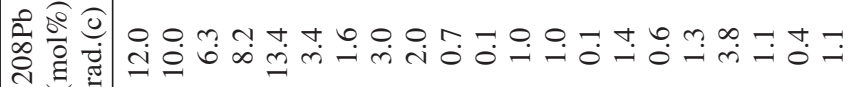

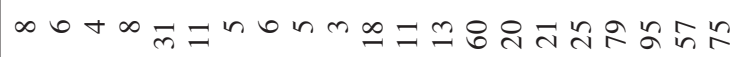

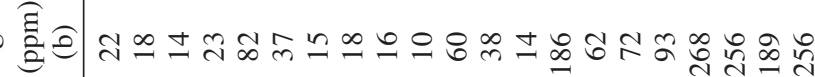

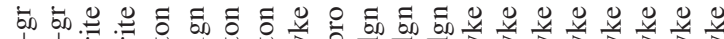
造

$4 x$ 员

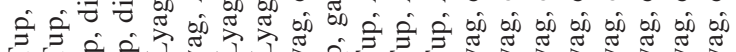

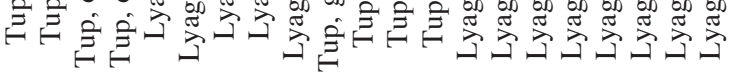

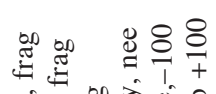

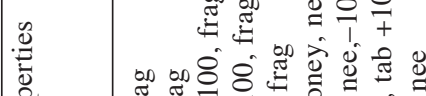
을

$\stackrel{\Sigma}{\Sigma}$ $\dot{i}$ $\frac{\sqrt{8}}{\frac{8}{3}}$ تृ

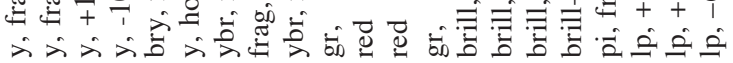

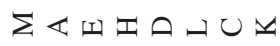

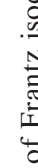

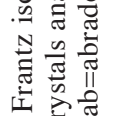

प⿺辶寸

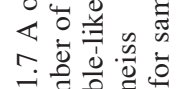

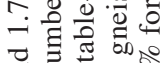

氙茾 :

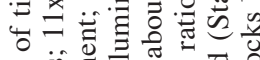

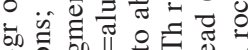
ข m.U.

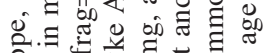
음 잉 过

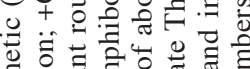
ฮิ 焉焉

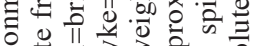

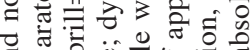

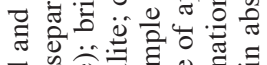
导

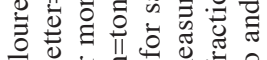

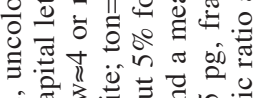

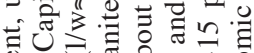

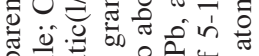

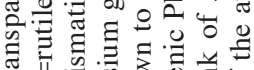

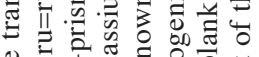

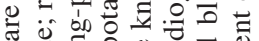
๙

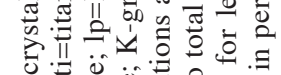
ปี.

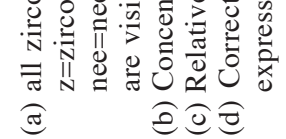



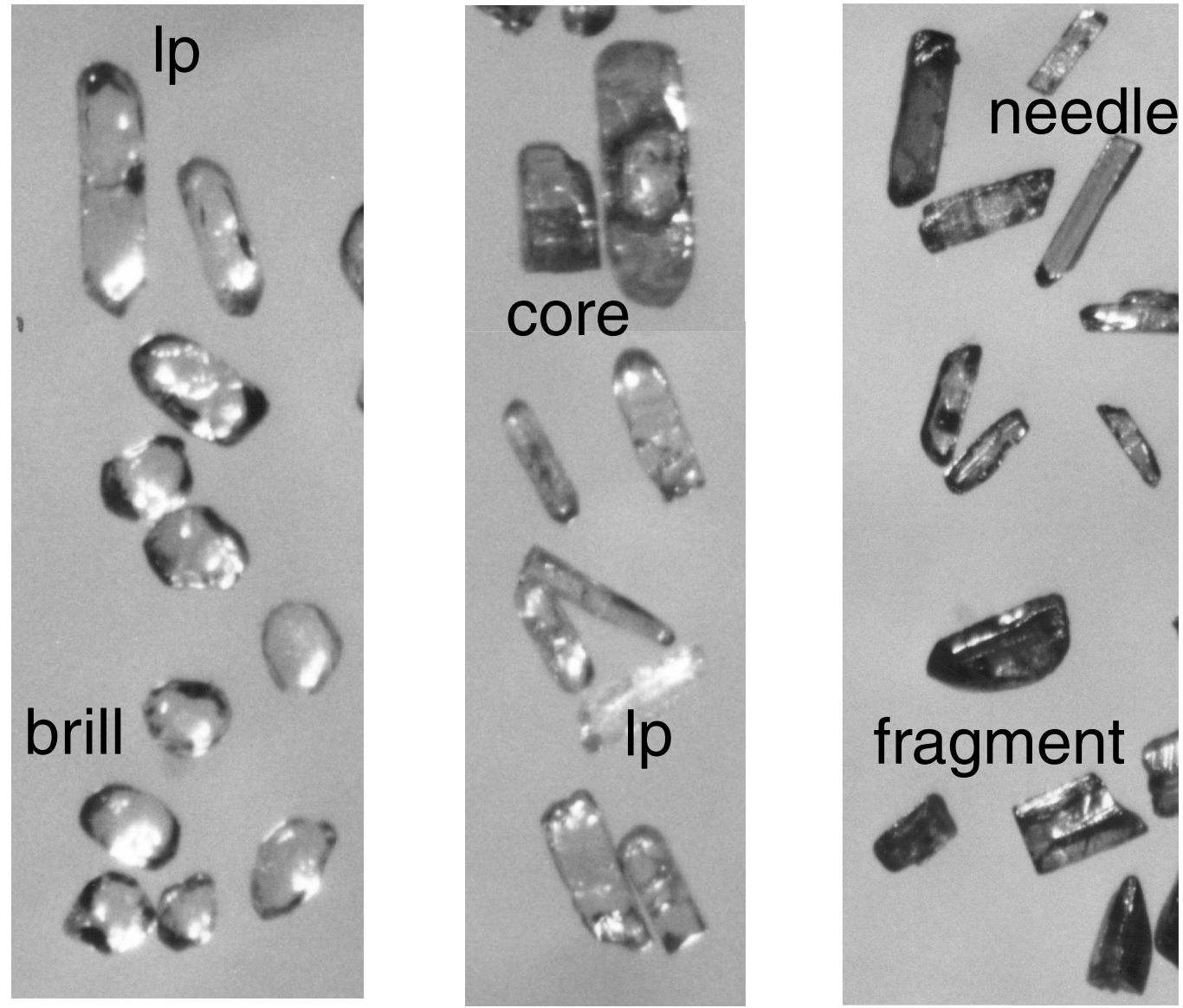

\section{Amphibolitic dyke zircons}

\section{1 rutiles}

Fig. 4. Transmitted light photographs of the type of zircons and rutiles present in the rock samples. The centralupper part exhibits some rejected and not analysed zircon crystals (ca. 90 um wide) with obvious cores. Abbreviations: lp=long prismatic; brill=brilliant type as in Table 2.

similar to those previously assessed for the latestage metamorphism which altered the aluminous kyanite-biotite-muscovite Chupa gneisses at Lyagkomina (Bibikova et al. 1993).

\section{$\mathrm{U}-\mathrm{Pb}$ isotopic data}

All the U-Pb isotopic data and ages are presented in Table 2, and those for the zircons are plotted in a Concordia diagram in Figure 3. Figures 4 and
5 display photographs of minerals of the kind analysed, like some of those rejected.

\section{Zircons.}

The zircon crystals from the investigated mafic dyke show only limited variability in morphology and style of crystallization. Most of them are transparent, short prismatic to isometric and have well-developed euhedral shapes, often with a high 


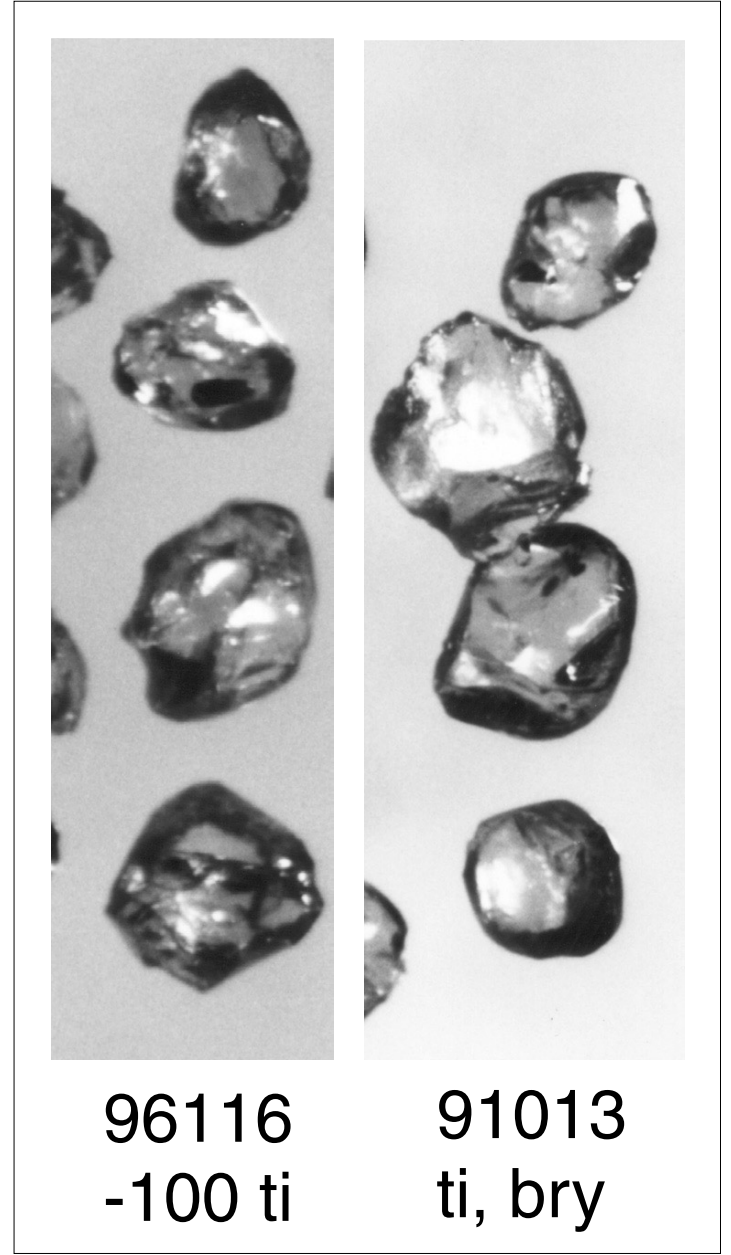

Fig. 5. Transmitted light photographs of the type of titanites analysed. Magnification as in Figure 4. Abbreviations correspond to those in Table 2.

lustre (lower left in Fig. 4). Clearly, these are not common features among mafic-dyke zircons. A minor proportion of the grains is elongated, longprismatic (upper left and centre of Fig. 4).

Some of the zircon analyses divert towards higher $\mathrm{Pb} / \mathrm{Pb}$ ages ( $>1900 \mathrm{Ma}$ ) than those of the transparent crystals, which in turn delimit the concordia-discordia upper-intercept age to $1875 \pm 4 \mathrm{Ma}$ (at 95\% confidence level and with a MSWD of 1.3).

\section{Titanites.}

In the present study, we have investigated titan- ite crystals both from the Lyagkomina and Tupaya Bay localities. The titanites have been separated from rocks which according to previous studies (Bibikova et al. 1996) and zircon ion-probe data (Claesson et al. in preparation) are Archaean and early Palaeoproterozoic in age. The analytical results, together with calculated ${ }^{207} \mathrm{~Pb} / 206 \mathrm{~Pb}$ ages, are presented in Table 2. Like titanites in general, the presently studied crystals (some examples are shown in Fig. 5) have low concentrations of uranium, leading to highly non-radiogenic $\mathrm{Pb}$-isotopic compositions. Still, all the titanites have concordant to almost concordant compositions indicating ages close to $1860 \mathrm{Ma}$.

\section{Rutiles.}

Rutile isotopic compositions and ages have been studied from some of the Archaean rocks in the study area. To judge from the high ${ }^{206} \mathrm{~Pb} /{ }^{204} \mathrm{~Pb}$ isotopic parameter, $\mathrm{Pb}$ in the rutiles is relatively radiogenic. Uranium contents are low, however, and it was a surprise to encounter concordant ages at about 1750 Ma.

Comparison with previous titanite and rutile $U$ $\mathrm{Pb}$ isotopic ages.

The titanite and rutile $\mathrm{U}-\mathrm{Pb}$ ages of this study compare well with the corresponding ages obtained during the regional study of the Belomorian Belt by Bibikova et al. (2001). In that paper, the titanite ages from the central part of the belt range between 1.82 and $1.87 \mathrm{Ga}$, while our ages have a range from 1.84 to $1.87 \mathrm{Ga}$. For rutile the equivalent ranges are $1.75-1.81$ and $1.74-1.78 \mathrm{Ga}$, respectively. In the present data set we find no systematic correlation between rutile ages and rock lithologies or other rock characteristics.

\section{DISCUSSION}

\section{Evidence from the P-T study}

The obtained data constrain the timing of the P-T and tectonic evolution of the crust in the Lyagkomina area. We suggest that the 1875-Ma zircon 


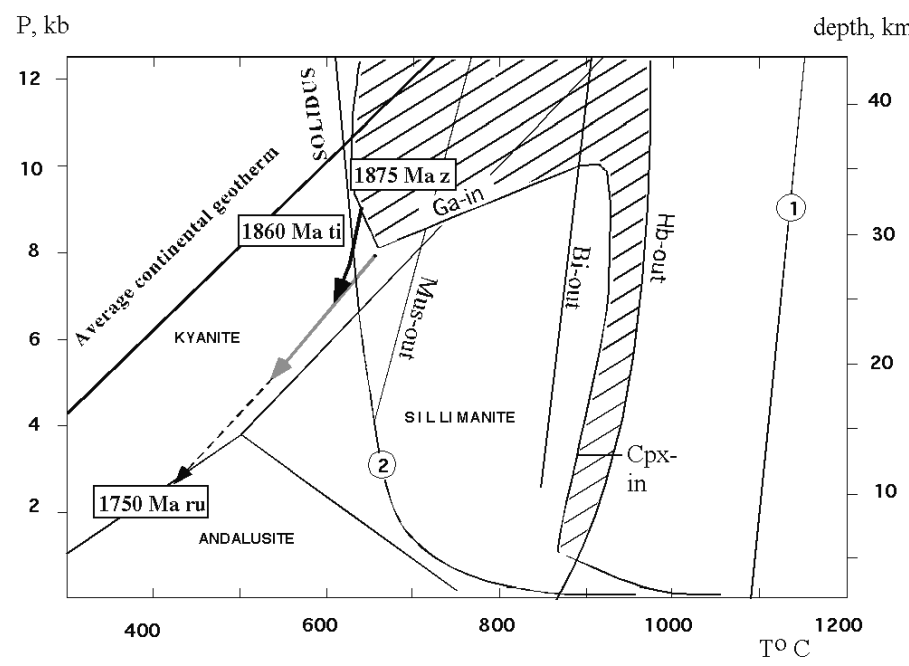

Fig. 6. P-T-t diagram showing the metamorphic evolution of the Lyagkomina garnet-amphibolitic dyke (black arrow) in comparison with the Palaeoproterozoic P-T trend of the host Archaean garnet-kyanite-biotite-muscovite gneisses (grey arrow). The dashed arrow shows a possible further evolution of the crust until rutile in the gneisses reached its closure temperature. The striped field indicates the P$T$ conditions of dehydration melting of amphibolite (after Wyllie \& Wolf 1993). The curves $10 \quad$ are. 1. dry gabbro solidus (Wyllie et al. 1981); 2. $\mathrm{H}_{2} \mathrm{O}$-saturated granite solidus (Huang \& Wyllie 1973); Muscovite-out dehydration melting of muscovite (after Thompson 1990); Biotite-out dehydration melting of biotite (Patino Douce \& Beard 1995).

age dates peak metamorphism in the mafic dyke. This took place close to $650^{\circ} \mathrm{C}$ at ca. 9 kbar (Fig. 6 ), but with the possibility that evidence of a still slightly higher peak temperature had been lost by element diffusion from the relatively small garnets of the dyke rock.

The indicated peak P-T conditions correspond to the earliest phase of recumbent folding of the dyke and its host rocks in the lower crust at depths of ca. $35 \mathrm{~km}$. Since the peak-metamorphic mineral assemblage is well within the solidus field, igneous crystallization of the dyke-rock melt had apparently been completed at that time. During that stage, new metamorphic zircon could grow rather easily due to the decomposition of pyroxene and other magmatic host minerals of zirconium (see papers in Chemical Geology 117, 1994).

Rims of plagioclase around garnets, changes of mineral compositions and the appearance of anatectic veining in the dyke and its surroundings, all indicate sudden decompression of the rocks and jump uplift of the crust with unroofing of approximately 9-10 km during the first stage of retrogression from peak conditions. This was an almost adiabatic process with little cooling. The average titanite age of ca. $1860 \mathrm{Ma}$, with the assumption of a $650-700^{\circ} \mathrm{C}$ closure temperature of its $\mathrm{U}-\mathrm{Pb}$ isotopic system, may indicate that this initial stage of the tectonothermal evolution lasted ca. $15 \mathrm{Ma}$ or even less. This corresponds to uplift rates of ca. $0.75 \mathrm{~mm} /$ year which appear to be a result of tectonic erosion and/or collapse of the crust after its thickening during the Lapland-Kola orogenic collision (cf. e.g. Harley 1992).

The change from compressional to extensional regime is supported by later refolding into open folds and penetrative ductile shearing. This latter structural development and cooling of the crust can be reconstructed using P-T estimates for the aluminous gneisses which host the analysed dyke (Bibikova et al. 1993). They document a prolonged and slower tectonothermal evolution during a 110-Ma period that is constrained by the titanite and rutile ages (Fig. 6). Such situations are typical for the uplift of lower crust in most Proterozoic high-grade terrains and imply thermal relaxation of the entire lithosphere to a steady-state geothermal regime (cf. Harley 1992).

The equivalent 1.9-1.75 Ga crustal development in the Tupaya Bay locality appears to have occurred at a shallower level in the crust. Very probably this difference was controlled by the Neoarchaean prehistory of the Lake Kovdozero region when the Lyagkomina rocks were buried ca. $7 \mathrm{~km}$ deeper in the crust than those in the Tupaya Bay area (cf. Bibikova et al. 1993, LobachZhuchenko et al. 1993). 


\section{Formation and age of the Lyagkomina mafic- dyke zircons}

Mafic magmas are low in silica, which commonly prevents the igneous crystallization of zircon. Even where there is free $\mathrm{SiO}_{2}$, zirconium ( $\left.\mathrm{Zr}\right)$ is commonly partitioned into pyroxenes and other dark minerals. In the presently investigated dyke, however, zircons are abundant. They are transparent, highly lustrous, and euhedral with only a limited number of simple crystal facets. This suggests crystallization during metamorphism rather than from melt.

During igneous crystallization of mafic rocks, Zr mostly enters dark minerals, mainly pyroxenes (Poldervaart, 1956) but also oxide opaques. If, however, some $\mathrm{Zr}$ remains and free $\mathrm{SiO}_{2}$ is enriched in the residual melt, zircon forms late, mostly as irregular and anhedral grains in the interstitial spaces. These are very different from the euhedral zircons found in the Lyagkomina dyke.

During metamorphism and the attendant decomposition of igneous minerals, $\mathrm{Zr}$ is released from pyroxene and opaques, while more $\mathrm{SiO}_{2}$ can rather easily be introduced by circulating fluids. The observed low contents of $U$ in the mafic-dyke zircons and their highly lustrous appearances indicate a metamorphic origin at relatively high P-T conditions (Bibikova 1984). The $1875 \pm 4$ Ma age determined from the high-quality zircons (Fig. 3) is therefore taken to date an early, high-T stage.

The remaining, considerably less abundant, Uricher mafic-dyke zircons have long-prismatic shapes and yield higher ${ }^{207} \mathrm{~Pb} /{ }^{206} \mathrm{~Pb}$ ages of 1954 and 2022 Ma. Most probably, these grains include xenocrysts which had been absorbed into the melt from the country-rocks. Zircons of that appearance are common in the nearby Neoarchaean tonalitic gneisses where complex growth and/or Pb-loss processes appear to have occurred. Assimilation of zircon xenocrysts into various rock melts (e.g. Pidgeon \& Aftalion 1978, Pidgeon et al. 1996) has been experimentally confirmed to reflect their high melting temperatures (Watson \& Harrison 1983). These are reasons why zircon xenocrysts can survive long in $\mathrm{Zr}$-saturated melts. They are common in granitic rocks and can occasionally complicate multi-grain U-Pb dating (cf. Eliasson \& Schöberg
1991). Felsic rocks are of course most easily saturated in $\mathrm{Zr}$, but xenocrysts have even been described from rapidly crystallized komatiites (Compston et al. 1985).

Experimental studies on the preservation of zircon U-Pb isotopic systems during melting (e.g. Bibikova et al. 1995) indicate that, although radiogenic $\mathrm{Pb}$ is easily lost from metamict domains, textures of crystalline zircon often remain unaffected even during prolonged heating to temperatures in excess of $1000^{\circ} \mathrm{C}$. It is plausible, however, that long-lasting elevated P-T conditions cause resorption of zircon xenocrysts if fluids are present, and that there is crystallization of new overgrowths on zircon seeds or entirely new crystals are formed (Skiöld 1986). We therefore consider that the presently analysed zircon xenocrysts may have preserved an isotopic memory of their primary crystallization.

\section{Cooling history as reflected by the ages of zircon, titanite and rutile}

Titanite growth and recrystallization can provide age estimates for deformational events associated with tectonometamorphic processes (see Resor et al. 1996, Getty \& Gromet 1992). Similarly, titanite and less commonly rutile have been used in geochronological studies for the determination of cooling histories in metamorphic terrains. In early studies (e.g. Mattison 1978, Tucker et al. 1987), the closure temperatures of $\mathrm{U}$ and $\mathrm{Pb}$ isotopes in titanite were considered to range between ca. 550 and $600{ }^{\circ} \mathrm{C}$. Later petrological-geochronological experiments, however, indicated higher temperatures of approximately $650^{\circ} \mathrm{C}$ (Mezger et al. 1991) and in excess of $700^{\circ} \mathrm{C}$ (Scott \& StOnge 1995, Zhang \& Schärer 1996, Pidgeon et al. 1996).

Diffusion parameters for $\mathrm{Pb}$ in variously-sized titanites have been determined by Cherniak (1993) using the diffusion equation of Dodson (1973). Cherniak's calculations for $300-\mu \mathrm{m}$ radius crystalline titanite in a rock with a cooling rate of $2^{\circ} \mathrm{C} /$ Ma suggest a closing temperature just above $700^{\circ} \mathrm{C}$. In comparison, the closure temperature for rutile is considerably lower. According to Mezger et al. (1989) U-Pb diffusion from 90-200 $\mu \mathrm{m}$ rutiles with 
a cooling rate of $1^{\circ} \mathrm{C} / \mathrm{Ma}$ closes at about $420^{\circ} \mathrm{C}$.

From petrographic investigation we conclude that the rutiles and titanites as well as the highly lustrous dyke zircons from Lyagkomina are all metamorphic. Although the titanites from both Lyagkomina and Tupaya Bay are low in uranium, which causes relatively large error, the data obtained are mostly concordant at approximately $1860 \mathrm{Ma}$. This means that ca. $1860 \mathrm{Ma}$ ago the metamorphic temperature in the Lyagkomina-Tupaya Bay area passed titanite blocking conditions at approximately $700^{\circ} \mathrm{C}$. The rutile age estimates are concordant at about $1750 \pm 10 \mathrm{Ma}$.

These observations and age determinations allow the estimation of cooling rates after peak metamorphism. The P-T measurements on mineral pairs indicate a metamorphic peak close to $650 \pm$ $30^{\circ} \mathrm{C}$ and ca. 9 kbar with possibly still higher maximum temperatures. This compares well with the experimental data preferring a closing temperature of roughly $700^{\circ} \mathrm{C}$ for titanite. Assuming a constant rate of cooling over the temperature interval from $700-650$ to $400^{\circ} \mathrm{C}$ between 1860 and $1750 \mathrm{Ma}$, a ratio of approximately $2.5^{\circ} \mathrm{C} / \mathrm{Ma}$ is obtained. However, cooling rates are more likely to vary over such a wide range of temperatures, being higher at the elevated temperatures that prevail during the early stages of cooling.

The difference between the closure ages for metamorphic zircon and titanite is not great but quite obvious. The mafic-dyke zircons of the Lyagkomina area are ca. $15 \mathrm{Ma}$ older than the metamorphic titanite ages from the 2.8-2.4 Ga country rocks. Nevertheless, it is unlikely that this age difference can be used to model cooling rates, where e.g. cooling from 850 to $700^{\circ} \mathrm{C}$ in $15 \mathrm{Ma}$ would suggest ca. $10^{\circ} \mathrm{C} / \mathrm{Ma}$. The reason is that we cannot anticipate or exclude that the highly lustrous zircons had grown after passing their blocking temperature in the environment prevailing in the studied area. In the discussion above we rather suggest that they crystallized from $\mathrm{Zr}$ released during metamorphism from its original igneous host minerals. Circulating metamorphic fluids have most probably contributed in such a process.

\section{SYNOPSIS AND CONCLUSIONS}

Combined $\mathrm{U}-\mathrm{Pb}$ isotopic and $\mathrm{P}-\mathrm{T}$ studies of minerals and mineral associations in the northern part of the Belomorian Belt have succeeded to assess the metamorphic evolution of that region in the late Palaeoproterozoic, in particular the time which followed upon the stacking and thickening of the Belomorian crust during the Lapland-Kola continental collision. The most important conclusions of the present study are:

- Highly lustrous metamorphic zircons in a Palaeoproterozoic mafic dyke now recrystallized into garnet-amphibolite reflect a stage of late Palaeoproterozoic metamorphism which peaked at approximately $1875 \pm 4$ Ma ago.

- Peak metamorphic conditions were in excess of ca. $650^{\circ} \mathrm{C}$ at 8.5 to $9.5 \mathrm{kbar}$, whereas mineral associations formed somewhat later indicate a following stage at ca. $630^{\circ} \mathrm{C}$ and $7-8$ kbar. Metamorphism thus occurred at a maximum depth of ca. $35 \mathrm{~km}$.

- In conjunction with the new isotopic ages, the obtained P-T data indicates a relatively shortlived stage of initially rapid, almost adiabatic decompression. This suggests sudden jump uplift of previously thickened crust and unroofing of ca. 9-10 km.

- Cooling immediately after the initial stage of decompression and strong crustal uplift were rapid processes. The rate then slowed down substantially as indicated by titanite $\mathrm{U}-\mathrm{Pb}$ ages of ca. $1860 \mathrm{Ma}$ and rutile ages of ca. $1750 \mathrm{Ma}$. During the ca. 110-Ma time interval between the indicated ages, the average cooling rate was ca. $2.5^{\circ} \mathrm{C} / \mathrm{Ma}$, presumably higher in the beginning of the time interval and lower at the end.

- The titanite and rutile $\mathrm{U}-\mathrm{Pb}$ ages measured in the present study virtually coincide with the ages previously obtained in the central Belomorian Belt during a much wider regional survey (Bibikova et al. 2001).

- Differences in titanite and rutile U-Pb ages as a function of lithological variations seem to be absent. 
ACKNOWLEDGEMENTS. We appreciate stimulating discussions within the IGCP-275 and 371 projects and the ongoing EUROPROBE Svekalapko cooperation. In particular we are indebted to Sven-Eric Hjelt and Steven Daly as conveners of the Svekalapko project, but also to Russian collegues in the Kola Science Centre Apatity, in Petrozavodsk and in St Petersburg for exchange of views and for logistic support during mapping and sampling missions. Special thanks are sent to Maria Bogdanova and Mikhail Esimov who harboured us in the Kovda region. T.S. and S.B. recognize support through grants from the Swedish Research Council and E.B. from the Swedish Royal Academy of Sciences.

\section{REFERENCES}

Balagansky, V.V., Bogdanova, M.N. \& Kozlova, N.E. 1986. Structural-Metamorphic Evolution of the Northwestern Belomorian Belt. Apatity: Kola Science Centre. 100 p. (in Russian).

Bibikova, E.V. 1984. The most ancient rocks in the USSR territory by $\mathrm{U}-\mathrm{Pb}$ data on accessory zircons. In: Kröner, A. (ed.) Archaean Geochemistry: The origin and evolution of the Archaean continental crust. Berlin, Heidelberg: Springer Verlag, 235-250.

Bibikova, E.V., Skiöld, T., Bogdanova, S.V., Drugova, G.M. \& Lobach-Zhuchenko, S.B. 1993. Geochronology of the Belomorides: an interpretation of the multistage geological history. Geokhimiya 10, 1393-1411 (in Russian).

Bibikova, E.V., Shilobreeva, S.N., Gracheva, T.V. \& Makarov, V.A. 1995. Experimental study of U-Pb isotopic system behavior in zircon in melt under different physical-chemical conditions. Geokhimiya N 8, 11001109 (in Russian).

Bibikova, E.V., Skiöld, T. \& Bogdanova, S.V. 1996. Age and geodynamic aspects of the oldest rocks in the Precambrian Belomorian Belt of the Baltic (Fennoscandian) Shield. In: Brewer, T.S. (ed.) Precambrian Crustal Evolution in the North Atlantic Region. Geological Society of London, Special Publication 112, 55-67.

Bibikova, E., Skiöld, T., Bogdanova, S., Gorbatschev, R. \& Slabunov, A. 2001. Titanite-rutile thermochronometry across the boundary between the Archaean Craton and the Belomorian Mobile Belt, eastern Baltic Shield. Precambrian Research 105, 315-330.

Bogdanova, S.V. 1996. High-grade metamorphism of 2.45$2.40 \mathrm{Ga}$ age in mafic intrusions of the Belomorian Belt in the northeastern Baltic Shield. In: Brewer, T.S. (ed.) Precambrian Crustal Evolution in the North Atlantic Region. Geological Society of London, Special Publication 112, 69-90.

Bogdanova, S.V. \& Bibikova, E.V. 1993. The "Saamian" of the Belomorian Mobile Belt: new geochronological constraints. Precambrian Research 64, 131-152.

Bridgwater, D., Marker, M. \& Mengel, F. 1992. The eastern extension of the Early Proterozoic Torngat orogenic zone across the Atlantic. In: Wardle, R.J. \& Hall, J. (eds.) Eastern Canadian Shield Onshore-Offshore Transect (ECSOOT). Lithoprobe report 27, 76-91.

Bridgwater, D., Glebovitsky, V.A. \& Sedova, I.S. 1994. Sub-horizontal stretching fabrics and high-grade metamorphic assemblages in 2.5-2.35 Ga syntectonic igneous suites from the Belomorian fold belt. Evidence of acid-basic igneous activity during extension in the deep crust. In: IGCP Symposium 275 and 371, Nottingham. Terra Nova 6, Abstract supplement 2, p. 4.

Cherniak, D.J. 1993. Lead diffusion in titanite and preliminary results on the effects of radiation damage on $\mathrm{Pb}$ transport. Chemical Geology 110, 177-194.

Compston W., Williams, I.S., Campbell, I.H. \& Gresham, J.J. 1985. Zircon xenocrysts from the Kambalda volcanics: age constraints and direct evidence for older continental crust below the Kambalda-Norseman greenstones. Earth and Planetary Science Letters 76, 299-311.

Daly, J.S., Balagansky, V.V., Timmerman, M.J., Whitehouse, M.J., de Jong, K., Guise, P., Bogdanova, S., Gorbatschev, R. and Bridgwater, D. 2001. Ion microprobe $\mathrm{U}-\mathrm{Pb}$ zircon geochronology and isotopic evidence for a trans-crustal suture in the Lapland-Kola Orogen, northern Fennoscandian Shield. Precambrian Research 105, 289-314.

Dodson, M.H. 1973. Closure temperature in cooling geochronological and petrological systems. Contributions to Mineralogy and Petrology 40, 259-274.

Eliasson, T. \& Schöberg, H. 1991. U-Pb dating of the postkinematic Sveconorwegian (Grenvillian) Bohus granite, SW Sweden: evidence of restitic zircon. Precambrian Research 51, 337-350.

Gaál, G. \& Gorbatschev, R. 1987. An outline of the Precambrian evolution of the Baltic Shield. Precambrian Research 35, 15-52.

Getty, S.R. \& Gromet, L.P. 1992. Geochronological constraints on ductile deformation, crustal extension, and doming about a basement-cover boundary, New England Appalachians. American Journal of Science 292, 359-397.

Harley, S.L. 1992. Proterozoic granulite terranes. In: Condie, K.C. (ed.) Proterozoic Crustal Evolution. Developments in Precambrian Geology. Amsterdam: Elsevier, 301-360.

Huang, W.L. \& Wyllie P.J. 1973. Melting relation of muscovite-granite to $35 \mathrm{kbar}$ as a model for fusion of metamorphosed subducted oceanic sediments. Contributions to Mineralogy and Petrology 42, 1-14.

Kohn, M.J. \& Spear, F.S. 1990. Two new geobarometers for garnet amphibolites, with applications to southeastern Vermont. American Mineralogist 75, 89-96.

Krogh, T.E. 1973. A low contamination method for hydrothermal decomposition of zircons and extraction of $U$ and $\mathrm{Pb}$ for isotopic age determinations. Geochimica et Cosmochimica Acta 37, 485-495.

Krogh, T.E. 1982. Improved accuracy of U-Pb zircon ages by the creation of more concordant systems using an air 
abrasion technique. Geochimica et Cosmochimica Acta 46, 637-649.

Lobach-Zhuchenko, S.B., Bibikova, E.V. \& Drugova, G.M. 1993. Geochronology and petrology of magmatic complexes of Tupaya Bay, North-West Belomorye. Petrologiya (Petrology) 1993:6, 657-677 (in Russian and English).

Lobach-Zhuchenko, S.B., Arestova, N.A., Chekulayev, V.P., Levsky, L.K., Bogomolov, E.S. \& Krylov, I.N. 1998. Geochemistry and petrology of 2.40-2.45 Ga magmatic rocks in the north-western Belomorian Belt, Fennoscandian Shield, Russia. Precambrian Research 92, 223-250.

Ludwig, K.R. 1991a. PBDAT: A computer program for processing $\mathrm{U}-\mathrm{Pb}-\mathrm{Th}$ isotope data. Version 1.20. United States Geological Survey, Open File Report 88-542.

Ludwig, K.R. 1991b. ISOPLOT: A plotting and regression program for radiogenic isotope data. Version 2.53. United States Geological Survey Open File Report 91.

Mattison, J.M. 1978. Age, origin and thermal history of some plutonic rocks from the Salinian block of California. Contributions to Mineralogy and Petrology 67, 233-245.

Mezger K., Hanson, G.N. \& Bohlen, S.R. 1989. High-precision $\mathrm{U}-\mathrm{Pb}$ ages of metamorphic rutile: application to the cooling history of high-grade terrains. Earth and Planetary Science Letters 96, 106-118.

Mezger, K., Rownsley, C.M., Bohlen, S.R. \& Hanson, G.N. 1991. U-Pb garnet, sphene, monazite and rutile ages: implications for the duration of high-grade metamorphism and cooling histories, Adirondack Mts, New York. Journal of Geology 99, 415-428.

Miller, Yu.V. \& Mil'kevich, R.I. 1995. Thrust-fold structure of the Belomorian zone and its correlation with the Karelian granite-greenstone region. Geotektonika 6, 80 93 (in Russian).

Miller, Yu.V., Glebovitsky, V.A., Bogdanova, S.V., Skiöld, T., Milkevich, R.I., Lvov, A.B. \& Myskova, T.A. 1995. The main stages in the structural development of the Belomorian Mobile Belt (BMB): Zarechensk - Tolstik geotraverse, NW Belomorian. In: IPGG-RAN, St Petersburg, Russia. MAEGS 9, Abstract p. 71.

Patino Douce, A.E. \& Beard, J.S. 1995. Dehydration melting of biotite gneiss and quartz amphibolite from 3 to 15 kbar. Journal of Petrology 36, 707-738.

Perchuk, L.L., Aranovich, L.Ya., Podlesskii, K.K., Lavrent'eva, I.V., Gerasimov, V.Yu., Fed'kin, V.V., Kitsul, V.I., Karsakov, L.P. \& Berdnikov, N.V. 1985. Precambrian granulites of the Aldan Shield, eastern Siberia, USSR. Journal of Metamorphic Geology 3, 265-310.

Pidgeon R.T. \& Aftalion M. 1978. Cogenetic and inherited zircon U-Pb system in granites from Paleozoic granites of Scotland and England. In: Bowes, D.R \& Leake, B.E. (eds.) Crustal evolution in Northwestern Britain and adjacent regions. Journal of Geology, Special Issue 10, $183-220$.

Pidgeon, R.T., Bosch, D. \& Bruguier, O. 1996. Inherited zircon and titanite U-Pb systems in an Archaean syenite from southwestern Australia: implications for $\mathrm{U}-\mathrm{Pb}$ stability of titanite. Earth and Planetary Science Letters 141, 187-198.

Plusnina, L.P. 1982. Geothermometry and geobarometry of plagioclase-hornblende bearing assemblages. Contributions to Mineralogy and Petrology 80, 140-146.

Poldervaart, A. 1956. Zircon in rocks. 2. Igneous rocks. American Journal of Science 254, 521-554.

Resor, P.G., Chamberlain, K.R., Frost, C.D., Snoke, A.W. \& Frost, B.R. 1996. Direct dating of deformation: U$\mathrm{Pb}$ age of syndeformational sphene growth in the Proterozoic Laramie Peak shear zone. Geology 24, 623-626.

Scott, D.J. \& StOnge, M.R. 1995. Constraints on Pb closure temperature in titanites based on rocks from the Ungava Orogen, Canada: Implications for U-Pb geochronology and P-T-t path determinations. Geology 23, $1123-1126$.

Skiöld, T. 1986. On the age of the Kiruna Greenstones. Precambrian Research 32, 35-44.

Skiöld, T., Bibikova, E., Slabunov, A.I. \& Bogdanova, S. 1997. The effect of Paleoproterozoic tectonothermal processes on titanite and zircon ages from the KarelianBelomorian assemblage of the Baltic Shield. Terra Nova 9, Abstract Suppl. 1, 129-130.

Spear, F.S., Peacock, S.M., Kohn, M.J., Florence, F.P. \& Menard, T. 1991. Computer programs for petrologic PT-t path calculations. American Mineralogist 76, 20092012.

Stacey, J.S. \& Kramers, J.D. 1975. Approximation of terrestrial lead isotope evolution by a two-stage model. Earth and Planetary Science Letters 26, 207-221.

Steiger, R.H. \& Jäger, E. 1977. Convention on the use of decay constants in geo- and cosmochronology. Earth and Planetary Science Letters 36, 359-362.

Stepanov, V.S. \& Slabunov, A.I. 1989. Amphibolites and early basite-ultrabasites of the Precambrian in northern Karelia. Leningrad: Nauka, 177 p. (in Russian).

Thompson, A.B. 1990. Heat, fluids, and melting in the granulite facies. In: Vielzeuf, D. \& Vidal, Ph. (eds.) Granulites and Crustal Evolution. The Netherlands: Kluwer Academic Publishers, 37-57.

Tucker, R.D., Råheim, A., Krogh, T.E. \& Corfu, F. 1987. Uranium-lead zircon and titanite ages from the northern portion of the Western Gneiss region, south-central Norway. Earth and Planetary Science Letters 96, 106-118.

Watson, E.B. \& Harrison, T.M. 1983. Zircon saturation revisited: temperature and composition effects in a variety of crustal magma types. Earth and Planetary Science Letters 64, 295-304.

Wyllie, P.J. \& Wolf, M.B. 1993. Amphibolite dehydration melting: sorting out the solidus. In: Prichard, H.M., Alabaster, T., Harris, N.B.W. \& Neary, C.R. (eds.) Magmatic Processes and Plate Tectonics. Geological Society of London Special Publication 76, 405-416.

Wyllie, P.J., Donaldson, C.H., Irving A.J., Kesson, S.E., Merrill, R.B., Presnall, D.C., Stolper, E.M., Usselman, T.M. \& Walker, D. 1981. Experimental petrology of basalts and their source rocks. In: Basaltic Volcanism Study Project. Basaltic Volcanism on the Terrestrial Planets. New York: Pergamon Press, 494-633.

Zhang, Sh.L. \& Schärer, U. 1996. Inherited Pb component in magmatic titanite and their consequence for the interpretation of $\mathrm{U}-\mathrm{Pb}$ ages. Earth and Planetary Science Letters 138, 57-65. 